\title{
TEACHING SPEAKING: EXPLORING METHOD OF TEACHING AND ORAL CORRECTIVE FEEDBACK IN EFL LEARNERS' CLASSROOM
}

\author{
Aldha Williyan \\ Universitas Negeri Semarang \\ alwilliyan@gmail.com
}

\begin{abstract}
This study investigates teaching speaking in EFL learners' classroom as teaching speaking is a vast area of research. This study, however, limits the focus to types of methods and oral corrective feedback. This study involves two groups of participants, namely a group of EFL learners and an English teacher. This qualitative study employs observation. Afterward, the unstructured interview with the English teacher is conducted to give further data. Through the observation, it is found that the teacher does some particular activities in teaching speaking. The lesson is opened by group work and the teacher conducts a dialogue and chain drill. The lesson eventually is closed by pair work and role play. The analysis shows that the teacher uses several methods in doing those five activities. Those are communicative language teaching, audiolingual method, and cooperative language learning. From those three, the audio-lingual method dominates the class activities. Additionally, this study finds that the teacher employs several types of oral corrective feedback. Those are recast, explicit correction, clarification requests, and elicitation. These findings indicate that there is a relationship between methods and oral corrective feedbacks used by the teacher.
\end{abstract}

Keywords: Teaching Method, Teaching Speaking, Oral Corrective Feedback, English Teacher

\section{INTRODUCTION}

This study aims to investigate how the teacher teaches speaking. Teaching speaking in EFL learners' classrooms nowadays is regarded as essential as a significant number of the population in the world uses English, and it is still growing (Harmer, 2007). This trend inevitably leads people to master English, especially speaking ability. With excellent speaking ability, people are more comfortable to survive in society because communication is dominated by the spoken language (Palmer, 2014). It means this ability is needed, and this study concerns on it. According to Gultom (2015), some methods often used by teachers in Indonesia are grammar-translation method, direct method, structural method, reading method, audio-lingual method, situational method, total physical response method, and communicative approach. Some of them are designed to improve speaking skills, and some of them are not. Therefore, through this study, methods used by the teacher to teach speaking are revealed.

Methods in teaching English have developed since a long time ago. Experts believe that teaching initially is conducted through one method called the grammar-translation method. The goal of it is to enable the learners to understand texts written in the target language (Larsen-Freeman, 2000). To do that, the teachers usually train the learners to translate the target language text into their native language or vice versa (Celce-Murcia, 2001). This method, however, is not deemed successful in enhancing the learners' speaking ability (Larsen-Freeman, 2000). Therefore, the direct method that forbids the learners to translate the text emerges (Larsen-Freeman, 2000). Another difference between both is the fact that the learners' indirect method is encouraged to comprehend the meaning and target language without studying it grammatically, but through actions and pictures (Celce-Murcia, 2001). Since then, experts begin to realize the importance of speaking skills and how to use the target language communicatively.

Unfortunately, the direct method also is not perfect. Since speaking in the mother tongue is not allowed in the direct method, to implement it, the teachers are required to have a good mastery of the target language. It is not easy to find teachers with this requirement. That is why teaching language is shifted to the reading method, which does not require teachers to have excellent speaking ability in the 
target language. In this method, teachers stress only some useful grammatical knowledge in order to enhance reading comprehension (Celce-Murcia, 2001).

Afterward, people begin to recognize the audio-lingual method. How these method works are influenced by an army program called the Army Specialized Training Program (ASTP). It equips the army to master the other languages used by the country. They will go by using 15 hours drill with native speakers (Richards \& Rodgers, 2001). No wonder, the audio-lingual method begins with dialog and drills the target structures from it in order to establish a new habit of the target language that can replace the old habit of the mother tongue (Larsen-Freeman, 2000). Those are conducted to create the learners who can use the target language communicatively (Richards \& Rodgers, 2001)

Like the other methods, this method has some challenges. First, it consumes much energy both for the teachers and learners. Second, the teaching and learning process is mostly dull as drilling dominates the activity. Besides, the biggest challenge is that the learners still face difficulties in real communication because drills can only form the learners' new habit of the target language inside the classroom. The audio-lingual method is also criticized by Chomsky, who believes that habit formation does not work in learning language, but the cognitive process does (Larsen-Freeman, 2000). These circumstances trigger the existence of another method, namely the silent method. It assigns the students to learn grammar exercises deductively, that is, learning the rule and applying it, and inductively, that is discovering the rule from examples and practicing it (Celce-Murcia, 2001). Hence, unlike the previous method, which focuses more on only a particular skill, this method focuses on four skills equally.

The silent method, however, is the lack of affective considerations (Celce-Murcia, 2001). Students cannot encourage themselves to get the maximum results as they are not comfortable in the class. The learners get better results when they are happy with what they do in the classroom. They are worried that they fail in the classroom (Larsen-Freeman, 2000). Luckily, this problem is solved by the existence of the new method called desuggestopedia. The main characteristic of it is that the teachers teach the learners cheerfully in a fun atmosphere (Larsen-Freeman, 2000). With this, the learners are expected to be able to implement the target language for communication faster.

The previous methods assign the learners to produce the target language directly. The experts begin to recognize that this is not a proper way because learning a foreign language is similar to learning the first language (Celce-Murcia, 2001). The babies initially cannot talk, but by the time they listen to the language as their input, they begin to talk. They talk when they feel that they are ready (Larsen-Freeman, 2000). Therefore, the comprehension-based approach, particularly total physical response, becomes popular. It believes that all skills begin with excellent listening skills. No wonder, based on the total physical response, the learners can only begin to produce language after the teachers assign them to react to specific command physically (Richards \& Rodgers, 2001).

Most of the previous methods concerns on how to enable the learners to communicate using the target language. With this, the learners indeed can use the target language inside the classroom, but they unfortunately still face difficulties to communicate outside the classroom (Larsen-Freeman, 2000). This situation encourages experts to develop another method to teach a foreign language. As a result, the communicative approach, particularly communicative language teaching, emerges in the world of teaching and learning a foreign language. Communicative language teaching allows the learners to communicate in the target language by focusing on linguistics forms, meanings, functions, social context, and the role of the speakers (Larsen-Freeman, 2000). No wonder, it is expected to be the solution to enable the learners to communicate both inside and outside the classroom as it aims to enhance the learners' communicative competence (Richards, 2006).

Based on the previous explanation, the final goal of methods in teaching foreign language has shifted from understanding written language into using it communicatively. This change is the evidence that speaking is essential. Furthermore, teaching speaking has developed from traditional ways that mostly assign the learners to repeat what the teachers say to the newest ways that consist of real communication activities (Richards, 2008: 02). However, there are still some difficulties that the teachers have to encounter. These difficulties are categorized based on teachers and students. In terms of teachers, the difficulties are in planning and implementing functional speaking activities. Meanwhile, in terms of students, the difficulties are their weak English mastery and passive engagement in the class (Chen \& Goh, 2011). This difficulty is the issue that encourages this study to give the real picture of teaching speaking in EFL learners' classroom.

Besides the method, the teachers are also required to pay attention to oral corrective feedback defined as responses given by either teachers or peers to errors produced in the learners' spoken language (Li, 2014). According to Lyster and Ranta (1997), oral corrective feedback is generally divided into six types. Those are explicit correction, recast, clarification request, metalinguistic feedback, elicitation, and repetition. In the newest work, they then categorize those six types into only two types. The first is reformulations that consist of recasts and explicit correction, and the second is prompts that 
consist of elicitation, metalinguistic feedback, clarification requests, and repetition (Ranta \& Lyster, 2007, cited in Lyster et al.: 2013). Recast is defined as the reformulation of teachers (Lyster \& Ranta, 1997 ) found as the most dominant type in many studies, such as in Lyster and Ranta (1997), Panova and Lyster (2002), and Suzuki (2004). It leads the researchers to research oral corrective feedback more.

Moreover, oral corrective feedback plays a crucial role in teaching speaking. It provides the learners scaffolding that develops their target language (Lyster et al.: 2013). The learners' interlanguage also is influenced by oral corrective feedback (Lyster \& Saito, 2010). In reality, it is, unfortunately, not given by the teachers carefully enough (Ganji, 2009). The fact that it is essential does not necessarily mean teachers use it without considerations as things relate to it are complex. The learners can miss the opportunity to relate form and function when the feedback is given. The ongoing communication also can be disturbed when the feedback is given (Lyster \& Ranta, 1997). Therefore, corrective feedback becomes popular in the world of ESL and another context of L2 researches (Panova \& Lyter, 2002), including this present study that deals with not only methods but also oral corrective feedback used by the teacher in teaching speaking.

\section{METHOD}

This present study employs a qualitative methodology. With this methodology, the behaviors can be identified (Fraenkel et al., 2012; Ary et al., 2010), particularly the ones which happen in teaching speaking. Additionally, this study deals with only one meeting course that runs in 80 minutes in only one class. This class is chosen because the lesson which is being taught is how to apply expression of intention communicatively. It is expected to support the study, which concerns on teaching speaking. Furthermore, the participants of this study are the teacher and EFL learners. Therefore, this study belongs to a case study that, according to Berg $(2001,225)$, deals with collecting the data from a particular person, social setting, event, or group.

Observation is employed to collect data. It is useful for qualitative study as it can provide the phenomenon that is researched (Alwasilah, 2015). The data are taken from the observation then is strengthened by the results of the unstructured interview defined as the interview whose questions are not listed but developed by the researchers (Dawson, 2007). The interview indeed has a goal to provide additional data that cannot be collected by the previous technique (Mackey \& Gass, 2005: 173). Besides, the interview is also commonly used by a case study, like this present study (Alwasilah, 2015). Thus, both techniques of collecting data are regarded as suitable to support the study.

\section{FINDINGS AND DISCUSSION}

Before analyzing the data further, it is necessary to transform all of it into the form of a transcript. Afterward, the researcher analyzes the data to find out the methods and oral corrective feedbacks used by the teacher in teaching speaking using the theories of Larsen-Freeman (2000), Richards \& Rodgers (2001), Celce-Murcia (2001), and Lyster and Ranta (1997). The results are discussed separately below.

\section{Communicative Language Teaching to Teach Speaking}

The class observed by the researcher is taught in around 80 minutes. Class activity consists of five main activities. The first activity is warming up in the form of group work. Then, it is continued with two different drill activities, namely dialogue and chain drills. In the third activity, the teacher assigns the learners to do one work in pairs. Lastly, the class is closed with the activity of pure role play. However, most of the learners do not feel this last stage as time is not enough. Below is Table 1, which provides more precise information regarding what the teacher does in the classroom.

Table 1. Teaching and Learning Activities

\begin{tabular}{|c|l|l|}
\hline No & Activities & Time \\
\hline 1. & Group Work & $20^{\prime}$ \\
\hline 2. & Dialogue Drill & $20^{\prime}$ \\
\hline 3. & Chain Drill & $15^{\prime}$ \\
\hline 4. & Pair Work & $15^{\prime}$ \\
\hline 5. & Role Play & $10^{\prime}$ \\
\hline
\end{tabular}

In the first activity, the teacher divides the class into some groups to do group works. All the boys are in the same group as there are only four boys, and the rest of nine students are divided into three groups with three learners in each. The teacher uses pictures of some famous cities from the learners' book with some additional ones from the slides as the media. He then asks the learners about the name of the locations and finally assigns them to chose two locations that they want to visit as well as the reasons. This opening activity aims to introduce the topic, which is about an expression of 
intention. It means that he does a warmer or lead-in activity that is the activity used by the teacher to introduce and activate the students' schemata (Harmer, 2007). Below is the excerpt from the teaching and learning activity taken from the observation.

\begin{tabular}{|l|l|}
\hline Teacher: & $\begin{array}{l}\text { I will show you some pictures and you have to guess where it is. But } \\
\text { you have to make groups. }\end{array}$ \\
\hline Students: & Boys one group, Sir. \\
\hline Teacher: & $\begin{array}{l}\text { OK, girls make group of three. After guessing, you have to choose two } \\
\text { places from pictures that you want to visit. Discuss in English, OK. }\end{array}$ \\
\hline
\end{tabular}

The excerpt above indicates that the warming up activity is actually communicative language teaching activity based on some considerations. First, by displaying pictures as the media to discuss, the teacher's role is to facilitate communication in the classroom (Larsen-Freeman, 2000). Second, it engages learners in communication through the activity of information sharing, negotiation meaning, and interaction (Richards \& Rodgers, 2001). Third, the use of English in almost all activities, during the explanation of the activity and communicative activity, also is what the communicative language teaching requires (Larseen-Freeman, 2000). Thus, the teacher, indeed at the beginning of the lesson, employed communicative language teaching, which concerns enhancing the communicative competence of the learners through an emphasis on group work (Richards, 2006).

\section{Audio-Lingual Method through Conversation Drill}

The next activity conducted by the teacher is a conversation drill. He points some learners to read the dialogue from the book. He drills the learners once he finds the wrong pronunciation. He does it many times until he is sure that all learners understand how to pronounce the words. Afterward, the activity is continued with a discussion regarding the content of the dialogue, which is about intention. Therefore, he also starts the conversation with the learners about their intention after graduation. Some of them say continuing study, finding works, and even getting married. Teaching and learning activity then come to the explanation of intention expressions. The additional expression lists are also displayed through the slides, and the drilling activity is conducted again to practice expressing those expressions correctly. Finally, the teacher explains the meaning of those expressions which are to express intention. Below is the excerpt from the teaching and learning activity taken from the observation.

\begin{tabular}{|l|l|}
\hline Student: & $\begin{array}{l}\text { Uhm, I'm not sure. I don't have any idea yet. I think I might stay at } \\
\text { home. (Read the dialogue with some errors in pronunciation) }\end{array}$ \\
\hline & $\begin{array}{l}\text { Alright, Safira (Student's name). Once again, once again. I'm not sure. } \\
\text { I don't have any “idea" yet. Any "idea" yet. I think I might stay at home. } \\
\text { Come on. (Teacher repeated the line and encouraged the student to } \\
\text { repeat) }\end{array}$ \\
\hline
\end{tabular}

Like this class, the class with the audio-lingual method begins with the dialogue (Celce-Murcia, 2001). It means the excerpt above indicates that the teacher employs the audio-lingual method. Also, this class in this activity uses the dialogue to present the structural patterns, which is one of the characteristics of the audio-lingual method (Larseen-Freeman, 2000). Then, audio-lingual classroom practices are drill, and one of the types is called a repetition defined as repeating an utterance aloud as soon as learners have heard it (Richards \& Rodgers, 2001). Based on those analyses, it is inferred that the teacher also employed the audio-lingual method through a conversation drill.

\section{Audio-Lingual Method through Chain Drill}

In the next activity, the teacher modifies the drill activity into chain drilling. He chooses one of the intention expressions, namely "to be going to." Then, he points one learner to make intention using that pattern and points another learner to use the same pattern with a different intention. Below is the excerpt from the teaching and learning activity taken from the observation that shows the implementation of a chain drill.

\begin{tabular}{|l|l|}
\hline Teacher: & Ok, Rayhan. Please make one intention using going to! \\
\hline Student: & I am going to walk. \\
\hline Teacher: & $\begin{array}{l}\text { Now, Farrel continue. You make one intention but before that mention } \\
\text { Rayhan's intention first. For example, he is going to walk and I am }\end{array}$ \\
\hline
\end{tabular}




\begin{tabular}{|l|l|}
\hline & going to bla bla bla... \\
\hline Student: & He is going to walk and I am going to pray. \\
\hline
\end{tabular}

There are some types of drills. One of them is the chain drill. Larsen-Freeman (2000) points out that the chain begins with the teacher asking a question to one learner who has to answer it and ask the same question to the student sitting next to him or her in order the chain continues until the last learner. This chain activity indicates that audio-lingual practices dominated the teaching speaking in this class as the teacher spent most of the time in these two stages. Through the interview, the teacher explained that this domination emerged because the learners mostly have low English mastery. They do not even know the correct pronunciation. That is why drills are conducted more in order to prepare them for the following communicative activities.

\section{Cooperative Language Learning to Teach Speaking}

It is necessary to inform the skills of the learners in this present study. There are thirteen learners in the classroom with only four boys, and the rest of them are girls when the observation is conducted. Based on the interview with the teacher, the girls generally have excellent skills in English. However, the boys are the opposite because there is one boy who is very weak in English. Therefore, the teacher in the next activity conducted pair work activity in order for the learners can assist each other. This activity requires the learners to discuss in pairs about the university and the department they want to study with the reasons as well as how to reach it using the expressions they have learned previously. Below is the excerpt from the teaching and learning activity taken from the observation.

\begin{tabular}{|l|l|}
\hline Teacher: & $\begin{array}{l}\text { Now, I will divide the class into groups that consist of two students. } \\
\text { Farrel with Rayhan, and you with Lukman (names of the students). } \\
\text { And the girls can choose by themselves. In pairs, you have to } \\
\text { discuss the university you want to study, the department, the } \\
\text { reason, and how to reach that intention. Please use the expression } \\
\text { we have learned before. }\end{array}$ \\
\hline Student: & Yes sir, ten minutes? \\
\hline Teacher: & Can you make it in 5 minutes? \\
\hline
\end{tabular}

From the excerpt above, it can be seen that the teacher selects the member of the pair selectively. One weak learner is grouped in pairs with the strong one. Through the interview with the teacher, he explains that he arranges those groups based on one consideration that is to help weak learners through learning from each other in groups (Larsen-Freeman, 2000). It indicates that the teacher employs cooperative language learning defined as "an approach designed to foster cooperation rather than competition, to develop critical thinking, and to develop communicative competence through socially structured interaction activities" (Richards \& Rodgers, 2001).

\section{Role Play to Teach Speaking}

The last activity conducted by the teacher is role play. The teacher displays the sample of dialogue through the slides. Then, he chooses two learners randomly to perform in front of the class, and they are allowed to use the results of the discussion from the previous activity for the contents of the conversation. Unfortunately, the time is spent too much on the previous activities. That is why many groups did not perform. Below is the excerpt of the teaching and learning activity taken from the observation.

\begin{tabular}{|l|l|}
\hline Teacher: & $\begin{array}{l}\text { Now, I will choose two of you randomly to come forwards and make } \\
\text { conversation like the one in the slide. The answers are from your } \\
\text { discussion with your partners. Dinar and Ajeng please... (students' } \\
\text { names) }\end{array}$ \\
\hline Students: & (Two of them performed) \\
\hline Teacher: & Good, now you can choose two of your friends to perform. \\
\hline
\end{tabular}

Applying role play, as shown in the excerpt above, indicates that the teacher implements communicative language teaching as it is done with communicative intent (Larseen-Freeman, 2000). Larseen-Freeman (2000) also points out that role play is essential in communicative language teaching, as the learners can practice communicating in different social contexts and different social roles. As a 
conclusion, three methods are employed by the teacher to teach speaking, namely communicative language teaching, audio-lingual method, and cooperative language teaching.

\section{CONCLUSIONS AND SUGGESTIONS}

This study has presented several findings, particularly methods and oral corrective feedbacks used by the teacher in one session of teaching English as a foreign language in one of the senior high schools in Cirebon, Indonesia. In conclusion, there are several things that the readers can learn through this one session investigation. First, it is not suggested for the teacher to teach the main topic in the first activity directly. A warmer or lead in the activity is suggested to open the lesson as it aims to relate the background knowledge of the learners with the topics (Harmer, 2007), for example, group work like in this study or other fun activities. Second, the audio-lingual method through drilling is also suggested in teaching speaking when the students have low English proficiency. With this, the teachers can minimize the obstacles in the following communicative activities, such as pronunciation problems through drilling (Larsen-Freeman, 2000). Third, the importance of drilling does not necessarily mean that teachers spend much time on it. In teaching speaking, they are suggested to conduct various communicative activities through communicative language teaching or cooperative language learning as both aim to encourage the learners to use the target language communicatively (Larsen-Freeman, 2000). Fifth, the teachers have to be smart when grouping the students. The groups are suggested to consist of learners with various English proficiency in order the cooperative language learning can work. Learners with low English proficiency can learn from those who have high English proficiency (LarsenFreeman, 2000)

Furthermore, it is found that the teacher is responding to learners' errors implements recast more than any other type of oral corrective feedback. The readers can learn from this finding that oral corrective feedback influences how well the learners develop their target language (Lyster \& Saito, 2010). The teachers thus have to be careful to implement certain types of oral corrective feedback in order to give positive influence to learners. Like this study, the other classes that consist of learners with low English proficiency are suitable for recast. In contrast, the teachers who teach learners with high English proficiency are not suggested to use recast as it can have a negative influence on the learners (Panova \& Lyter, 2002). As a solution, the teachers are suggested to use prompts instead of implementing recast (Lyster, 2004).

Lastly, there are several suggestions for further study in order to enrich the findings in the area of methods of teaching and oral corrective feedback. First, the results of this present study cannot be generalized as it depends on several factors such as students' age, L1 background, the purpose of learning the target language, and the goal of the class (Suzuki, 2004). That is why it is suggested to conduct the study concerning how the teachers teach speaking and respond to the learners' errors in the class with different learners' age, such as elementary and high school. Second, it is also suggested for future research to concern about revealing the effectiveness of certain types of methods and oral corrective feedback in enhancing the learners' speaking skills. Last but not least, the future researchers are also suggested to deal with how the teachers teach writing and respond to the learners' errors in written language.

\section{REFERENCES}

Alwasilah, A.C. (2015). Pokoknya Studi Kasus: Pendekatan Kualitatif. Bandung: Kiblat Buku Utama.

Ary, D. Jacobs, L. C. Razavieh, A. \& Sorensen, C. (2010). Introduction to Research in Education. 8th Edition. Belmont: Thomson Wadsworth.

Berg, B.L. (2001). Qualitative Research Methods for the Social Sciences. Boston: Pearson.

Celce-Murcia, M. (2001). Language Teaching Approaches: An Overview. In Celce-Murcia, M. (2001). (Ed). Teaching English as a Second or Foreign Language. USA: Heinle and Heinle, Thomas Learning.

Chen, Z. \& Goh, C. (2011). Teaching Oral English in Higher Education: Challenges to EFL teachers. AsiaPacific Journal of Teacher Education, 16(3), 333-345.

Dawson, C. (2007). A Practical Guide to Research Methods: A User-Friendly Manual for Mastering Research Techniques and Projects. Third Edition. United Kingdom: How to Books.

Fraenkel, J. R. Wallen, N. E. \& Hyun, H. H. (2012). How to Design and Evaluate Research in Education. New York: McGraw-Hill.

Ganji, M. (2009). Teacher-correction, Peer-correction, and Self correction: Their Impacts on Iranian Students' IELTS Essay Writing Performance. Journal of Asia TEFL, 6(1), 117-139.

Gultom, E. (2015). English Language Teaching Problems in Indonesia. Paper presented at the 7th International Seminar on Regional Education. https://ejournal.unri.ac.id/index.php/ISRE/ article/view/3235. 
Aldha Williyan

Harmer, J. (2007). The Practice of English Language Teaching. New York: Pearson Longman.

Larsen-Freeman, D. (2000). Techniques and Principle in Language Teaching. New York: Oxford University Press.

Li, S. (2014). Key Concepts in ELT Oral Corrective Feedback. ELT Journal, 68(2), 196-198.

Lyster, R. \& Ranta, L. (1997). Corrective Feedback and Learner Uptake: Negotiation of Form in Communicative Classrooms. Studies in Second Language Acquisition, 19(1), 37-66.

Lyster, R. \& Saito, K. (2010). Oral feedback in classroom SLA: A meta-analysis. Studies in Second Language Acquisition, 32, 265-302.

Lyster, R. (2004). Differential effects of prompts and recasts in form-focused instruction. Studies in Second Language Acquisition, 26(3), 399-432.

Lyster, R. Saito, K. \& Sato, M. (2013). Oral corrective feedback in second language classrooms. Language Teaching, 46(1), 1-40.

Mackey, A. \& Gass, S. M. (2005). Second Language Research Methodology and Design. New Jersey: Lawrence Erlbaum Associates, Inc., Publishers.

Palmer, E. (2014). Teaching the Core Skills of Listening and Speaking. Alexandria: ASCD.

Panova, I. \& Lyster, R. (2002). Patterns of Corrective Feedback and Uptake in an Adult ESL Classroom. TESOL Quarterly, 36(4), 573-595.

Richards, J. C. \& Rodgers, T. S. (2001). Approaches and Methods in Language Teaching. Cambridge: Cambridge University Press.

Richards, J. C. (2006). Communicative Language Teaching Today. Cambridge: Cambridge University Press.

Richards, J. C. (2008). Teaching Listening and Speaking: From Theory to Practice. Cambridge: Cambridge University Press.

Suzuki, M. (2004). Corrective Feedback and Learner Uptake in Adult ESL Classrooms. Teachers College, Columbia University Working Papers in TESOL \& Applied Linguistics, 4(2), 1-21. 